\title{
THE COMPETITION BETWEEN P-AMINO-HIPPURIC ACID (PAH) AND DIODRAST FOR RENAL EXCRETION AND EXTRACTION IN MAN ${ }^{1}$
}

\author{
BY BERTIL JOSEPHSON, JAN EK, HÄRJE BUCHT, LARS WERKÖ, \\ JULIA KALLAS, AND ARNE GRIEG \\ (From the Central Clinical Laboratory and the IV:th Medical Service, St. Erik's Hospital,
Stockholm, Sweden)
}

(Submitted for publication July 24, 1952; accepted July 30, 1953)

The competition between two substances for tubular excretion has been demonstrated repeatedly with orthodox clearance techniques. Smith, Goldring, and Chasis (1) found that raising the plasma concentration of diodrast depressed the excretion of phenol red. They concluded that both substances were excreted by the same mechanism. Similarly, it has been reported that intravenously administered diodrast (2) or PAH (3) retard the excretion of penicillin, that hippuric acid depresses the tubular excretion of glucuronic acid derivatives in the chicken (4), and that the amide of methyl-nicotinic acid depresses the tubular excretion of guanidine (5). Recently, it has been demonstrated that PAH in sufficient concentrations excludes phenol red from the cells or lumen of fish tubules suspended in appropriate salt solutions (6).

Smith, Finkelstein, Aliminosa, Crawford and Graber (7) found that diodrast and $\mathrm{PAH}$ given simultaneously had approximately the same renal clearance in man when the plasma concentration of both was low. They concluded that the two substances were excreted by the same mechanism. In none of these previous studies has the simultaneous renal extraction of the examined substances been investigated by analysis of renal vein blood. In fact, although it has been reported that renal extraction of diodrast is lower than that of PAH (8), there have been no published reports of simultaneous measurements of extraction of the two substances.

In the present study, the renal percentage extraction (E) and the tubular excretion ( $T$ ) of diodrast and $\mathrm{PAH}$ in man were simultaneously compared in experiments during which the plasma

\footnotetext{
1 The investigation was aided by grants from the Swedish Medical Research Council and the foundation "Thérèse och Johan Anderssons Minne."
}

concentration of one or both was varied over wide limits.

By "renal extraction," $\mathrm{E}$, is meant the percentage of a solute removed from the plasma during the passage of blood through the kidneys. Thus,

$$
\mathrm{E}=\frac{\mathrm{A}_{\mathrm{c}}-\mathrm{V}_{\mathrm{c}}}{\mathrm{A}_{\mathrm{c}}} \cdot 100 \text {, }
$$

where $A_{c}$ is the concentration of a solute in the arterial plasma and $V_{c}$ is the concentration of the same solute in the renal venous plasma.

By the tubular excretion, $T$, is meant the difference between the total amount of a solute excreted per minute in the urine and the amount of this solute filtered through glomeruli. The filtered quantity is calculated as the product of the inulin clearance and the filterable fraction of the plasma diodrast or $\mathrm{PAH}$, which generally are considered to be 73 and 83 per cent of the total plasma concentrations, respectively.

\section{MATERIAL AND METHODS}

Seventeen healthy young volunteers-medical students and nurses-were studied in the morning in the postabsorptive state. In fifteen of the experiments, a Goodale catheter was placed in the right renal vein under fluoroscopic control. An indwelling needle was placed in a brachial artery and a catheter placed in the bladder. After each clearance period the bladder was emptied and rinsed twice with distilled water and subsequently with air. At the beginning and end of each clearance period, blood samples were simultaneously collected from the brachial artery and the renal vein, transferred to heparinized tubes, and centrifuged within 5 minutes.

In experiments 1 and 2 (Table I, Figure 1), by first giving an intramuscular injection of $\mathrm{PAH}$, a low and comparatively steady plasma concentration was achieved (9). After one or two control periods, by giving an intramuscular injection of diodrast, ${ }^{2}$ a low and fairly

$2 \mathrm{We}$ are indebted to A. B. Astra Co., Södertälje, Sweden, for generously supplying us with 35 per cent Umbradil (diodrast). 
TABLE I

Results of renal vein catheterization experiments 1 to 4

\begin{tabular}{|c|c|c|c|c|c|c|c|c|c|c|c|c|c|c|c|c|c|c|}
\hline \multirow[b]{2}{*}{$\begin{array}{l}\text { Exp. } \\
\text { no. }\end{array}$} & \multirow[b]{2}{*}{ Subject } & \multirow[b]{2}{*}{$\begin{array}{l}\text { Min- } \\
\text { utes }\end{array}$} & \multirow[b]{2}{*}{ In.t } & \multicolumn{6}{|c|}{ PAH } & \multicolumn{6}{|c|}{ Diodrast } & \multirow[b]{2}{*}{$\frac{\mathrm{Cl}_{\mathrm{D}}}{\mathrm{Cl}_{\mathbf{P A B}}}$} & \multirow[b]{2}{*}{$\frac{E_{D}}{E_{P A B}}$} & \\
\hline & & & & A.t & Ef & Clt & RPF & $T \ddagger$ & $\frac{10 T t}{A_{0}}$ & $A_{0}$ & $\mathbf{E}$ & $\mathrm{Cl}$ & RPF & $\mathbf{T}$ & $\frac{10 \mathrm{~T}}{\mathrm{~A}_{0}}$ & & & \\
\hline $1 *$ & $\begin{array}{l}\text { Man, } \\
26 \text { y., } \\
\text { b.s.a. } \\
2,01\end{array}$ & $\begin{array}{l}13 \\
27 \\
15 \\
26 \\
14\end{array}$ & $\begin{array}{l}106 \\
120 \\
116 \\
109 \\
101\end{array}$ & $\begin{array}{l}60 \\
67 \\
72 \\
86 \\
80\end{array}$ & $\begin{array}{l}92 \\
91 \\
91 \\
63 \\
61\end{array}$ & $\begin{array}{l}592 \\
590 \\
616 \\
456 \\
536\end{array}$ & $\begin{array}{l}644 \\
649 \\
671 \\
724 \\
880\end{array}$ & $\begin{array}{l}27 \\
33 \\
37 \\
31 \\
36\end{array}$ & $\begin{array}{l}4,5 \\
4,9 \\
5,2 \\
3,6 \\
4,5\end{array}$ & $\begin{array}{r}40 \\
544\end{array}$ & $\begin{array}{l}72 \\
59\end{array}$ & $\begin{array}{l}568 \\
508\end{array}$ & $\begin{array}{l}789 \\
861\end{array}$ & $\begin{array}{r}27 \\
221\end{array}$ & $\begin{array}{l}6,9 \\
4,1\end{array}$ & $\begin{array}{l}0,92 \\
0,95\end{array}$ & $\begin{array}{l}0,78 \\
0,97\end{array}$ & $\begin{array}{l}\text { Diodr.intramusc. } \\
\text { Start diodr. infus. }\end{array}$ \\
\hline $2^{*}$ & $\begin{array}{c}\text { Woman, } \\
26 \text { y., } \\
\text { b.s.a. } \\
1,73\end{array}$ & $\begin{array}{l}32 \\
14 \\
29 \\
15 \\
16\end{array}$ & $\begin{array}{l}133 \\
133 \\
164 \\
190 \\
142\end{array}$ & $\begin{array}{l}61 \\
52 \\
51 \\
46 \\
38\end{array}$ & $\begin{array}{l}87 \\
85 \\
58 \\
61 \\
62\end{array}$ & $\begin{array}{l}806 \\
746 \\
715 \\
792 \\
720\end{array}$ & $\begin{array}{r}926 \\
877 \\
1,233 \\
1,298 \\
1,161\end{array}$ & $\begin{array}{l}42 \\
33 \\
29 \\
29 \\
23\end{array}$ & $\begin{array}{l}6,9 \\
6,2 \\
5,7 \\
6,3 \\
6,0\end{array}$ & $\begin{array}{r}87 \\
418 \\
323\end{array}$ & $\begin{array}{l}81 \\
54 \\
57\end{array}$ & $\begin{array}{l}673 \\
687 \\
665\end{array}$ & $\begin{array}{r}832 \\
1,270 \\
1,166\end{array}$ & $\begin{array}{r}49 \\
229 \\
185\end{array}$ & $\begin{array}{l}5,5 \\
5,5 \\
5,7\end{array}$ & $\begin{array}{l}0,90 \\
0,87 \\
0,92\end{array}$ & $\begin{array}{l}0,95 \\
0,88 \\
0,92\end{array}$ & $\begin{array}{l}\text { Diodr.intramusc. } \\
\text { Start diodr. infus. }\end{array}$ \\
\hline $3 t$ & $\begin{array}{l}\text { Man, } \\
21 \text { y., } \\
\text { b.s.a. } \\
1,92\end{array}$ & $\begin{array}{l}24 \\
31 \\
18 \\
29 \\
13\end{array}$ & $\begin{array}{l}116 \\
142 \\
122 \\
147 \\
137\end{array}$ & $\begin{array}{r}76 \\
1,010\end{array}$ & $\begin{array}{l}93 \\
61\end{array}$ & $\begin{array}{l}652 \\
505\end{array}$ & $\begin{array}{l}700 \\
827\end{array}$ & $\begin{array}{r}41 \\
392\end{array}$ & $\begin{array}{l}5,4 \\
3,9\end{array}$ & $\begin{array}{r}189 \\
110 \\
83 \\
79 \\
71\end{array}$ & $\begin{array}{l}83 \\
89 \\
86 \\
70 \\
67\end{array}$ & $\begin{array}{l}726 \\
945 \\
772 \\
557 \\
463\end{array}$ & $\begin{array}{r}874 \\
1,060 \\
897 \\
796 \\
691\end{array}$ & $\begin{array}{l}25 \\
29 \\
27 \\
18 \\
14\end{array}$ & $\begin{array}{l}1,3 \\
2,7 \\
3,2 \\
2,3 \\
2,0\end{array}$ & $\begin{array}{l}1,18 \\
0,92\end{array}$ & $\begin{array}{l}0,92 \\
1,10\end{array}$ & $\begin{array}{l}\text { PAH intramusc. } \\
\text { Start PAH infus. }\end{array}$ \\
\hline $4 \dagger$ & $\begin{array}{l}\text { Man, } \\
24 \text { y., } \\
\text { b.s.a. } \\
1,83\end{array}$ & $\begin{array}{l}17 \\
26 \\
12 \\
21 \\
11 \\
12\end{array}$ & $\begin{array}{l}134 \\
131 \\
124 \\
131 \\
131 \\
130\end{array}$ & $\begin{array}{r}150 \\
1,133 \\
1,256\end{array}$ & $\begin{array}{l}56 \\
55\end{array}$ & $\begin{array}{l}425 \\
396\end{array}$ & $\begin{array}{l}654 \\
759 \\
721\end{array}$ & $\begin{array}{r}74 \\
353 \\
357\end{array}$ & $\begin{array}{l}3,1 \\
2,8\end{array}$ & $\begin{array}{r}141 \\
124 \\
80 \\
72 \\
66 \\
59\end{array}$ & $\begin{array}{l}85 \\
86 \\
81 \\
76 \\
53 \\
48\end{array}$ & $\begin{array}{l}722 \\
583 \\
669 \\
669 \\
645 \\
526\end{array}$ & $\begin{array}{r}848 \\
678 \\
827 \\
879 \\
1,218 \\
1,095\end{array}$ & $\begin{array}{l}88 \\
60 \\
46 \\
41 \\
36 \\
26\end{array}$ & $\begin{array}{l}6,2 \\
4,9 \\
5,7 \\
5,7 \\
5,5 \\
4,3\end{array}$ & $\begin{array}{l}1,11 \\
1,52 \\
1,33\end{array}$ & $\begin{array}{l}0,89 \\
0,95 \\
0,87\end{array}$ & $\begin{array}{l}\text { PAH intramusc. } \\
\text { Start PAH infus. } \\
\text { Illness }\end{array}$ \\
\hline
\end{tabular}

* In experiment 1-2, a low arterial plasma concentration of PAH was maintained and that of diodrast was increased to high levels.

In experiments 3-4, a low diodrast concentration was maintained, and the PAH concentration increased.

$\ddagger \quad$ In $=$ inulin clearance,

$\mathrm{A}_{0}=$ arterial plasma concentration in $\mu$-mol./L.,

$\mathrm{E}=$ apparent renal percentage extraction,

$\mathrm{Cl}=$ renal clearance in $\mathrm{ml} . / \mathrm{min}$.,

$\mathrm{RPF}=\frac{\text { clearance }}{\mathrm{E}} 100$,

$\mathrm{T}=$ calculated tubular excretion in $\mu-\mathrm{mol} . / \mathrm{min}$., $\mathrm{y}=$ years,

b.s.a. = body surface area in $\mathrm{m}^{2}$.

steady plasma concentration of this substance was also attained (10). When the simultaneous excretion of the two substances had been observed for a sufficient time at these low plasma concentrations, the diodrast concentration was increased by giving a constant intravenous infusion until one or two more periods had been concluded.

In experiments 3 and 4 (Table I, Figure 1), the experimental design was the same but the order in which the substances were given was reversed, diodrast being given first and at low concentrations only.

In the experiments 5 to 9 (Table II), both substances were given simultaneously in equimolecular quantities. In experiment 5 (Figure 2), intramuscular injections were supplemented by constant, sustained intravenous infusions of both. At first, only a comparatively high concentration was effected, followed by a very high one of both substances. In experiments 6 to 9 (Table II), $\mathrm{PAH}$ and diodrast were given in equimolecular amounts by intravenous infusion only. Thus, initially, the concentrations were comparatively high and subsequently very high. In experiments 6 and 7, the renal vein was not catheterized.

In eight other experiments (Table III), a comparison was made between the simultaneous renal extractions, $\mathrm{E}$, and clearances, $\mathrm{Cl}$, of diodrast and $\mathrm{PAH}$ at low plasma concentrations only, which were sustained by simultaneous intramuscular injections.

In five experiments, the influence of the time interval between sampling and centrifugation was studied by a method similar to that described by Phillips, Dole, Hamilton, Emerson, Archibald, and Van Slyke (11). A large renal venous blood sample was drawn rapidly in subjects given both $\mathrm{PAH}$ and diodrast. An aliquot of each sample was centrifuged within 40 to 80 seconds and others after longer intervals up to $20 \mathrm{~min}$. By using an angle centrifuge with accelerations up to 8,000 r.p.m., the blood was separated in a few seconds so that the time of centrifugation was negligible. Then, the plasma was analyzed for diodrast and PAH by the usual method, slightly modified for the small concentrations. 


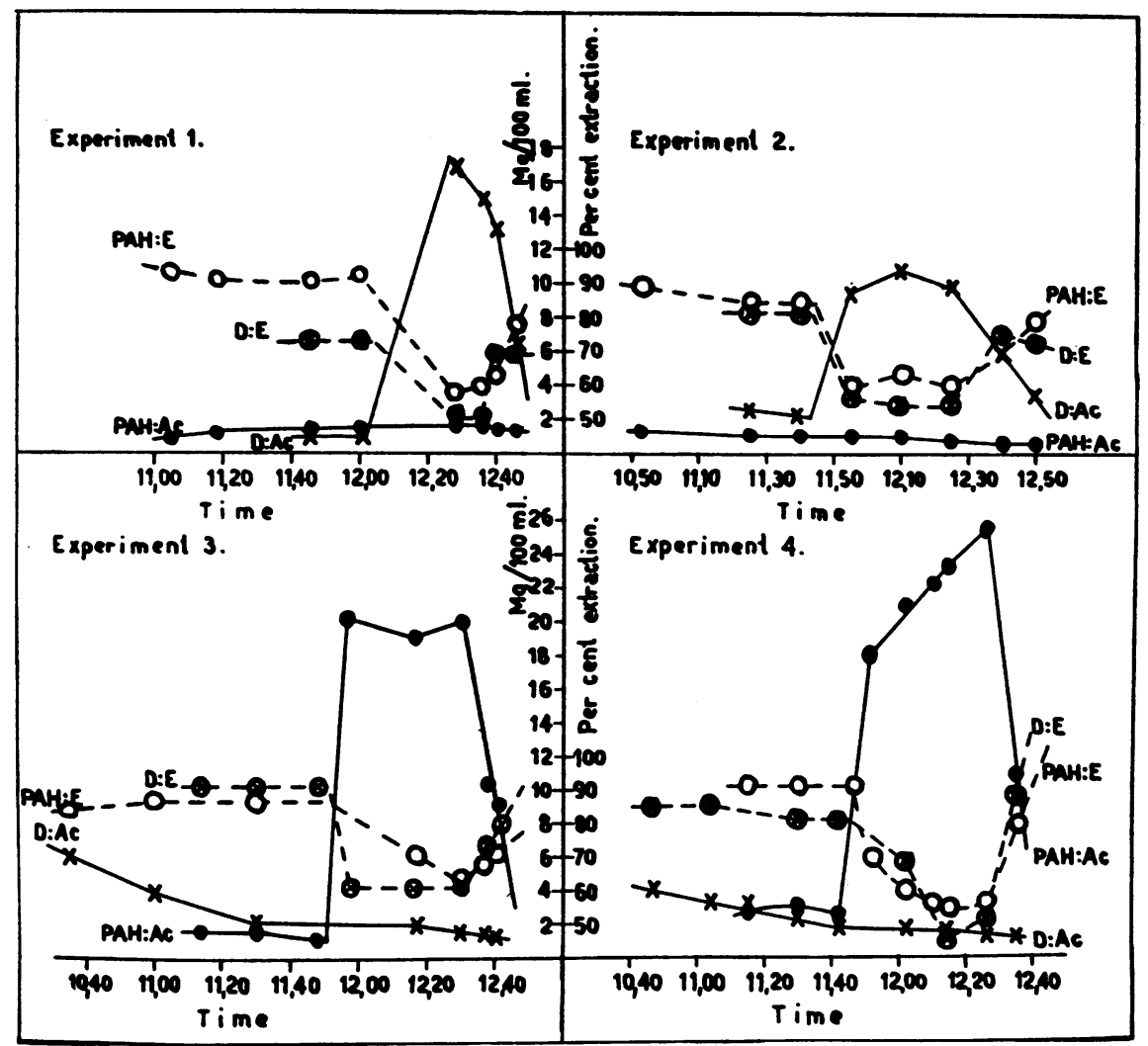

Fig. 1. Results of Renal Vein Catheterization-Experiments 1-4

- = arterial plasma PAH concentration (PAH: Ac); $\mathrm{O}=$ apparent percentage PAH extraction (PAH:E) $x=$ arterial plasma diodrast concentration (D:Ac) ; $\otimes=$ apparent percentage diodrast extraction $(D: E)$.

The details of the methods used, abbreviations and calculations, are described in previous publications from this laboratory $(12,13,14)$.

\section{RESULTS}

Table I contains the interpolated concentration in arterial blood plasma $\left(\mathrm{A}_{\mathrm{c}}\right)$, the interpolated renal extraction $(\mathrm{E})$, the renal clearance (C1), the estimated renal plasma flow ("RPF") and the tubular excretion ( $\mathrm{T}$ ) for both $\mathrm{PAH}$ and diodrast for the experiments, in which the concentration of only one substance was increased. In Figure 1, the corresponding actual extraction values and arterial plasma concentrations are presented. It is evident that when the concentration of both was low, the extraction of diodrast was slightly lower than that of PAH. When the concentration of either test substances was increased, the extraction of both decreased, al- though the arterial content of the other was actually lower than during the control period.

In Table II and Figure 2, the results obtained during administration of high, equimolecular concentrations of $\mathrm{PAH}$ and diodrast are presented. When the concentrations were increased, there generally was a parallel fall in the extraction of both substances. When calculated on the usual basis of a filterability of 83 per cent for $\mathrm{PAH}$ and 73 per cent for diodrast, the tubular excretion, $T$, did not remain constant. The ratio $T / A_{c}$ for $\mathrm{PAH}$ and diodrast is included as a comparative index of affinity for tubular excretion in the mutual competition.

In Table III are summarized the results of the first simultaneous and complete period from each low concentration experiment. The ratio of the PAH clearance to the diodrast clearance varied considerably in some of the experiments, but the 
TABLE $\mathbf{I}^{*}$

Results of experiments 5 to 9 with high equimolecular plasma concentration of $P A H$ and diodrast

\begin{tabular}{|c|c|c|c|c|c|c|c|c|c|c|c|c|c|c|c|c|c|}
\hline \multirow[b]{2}{*}{$\begin{array}{l}\text { Exp. } \\
\text { no. }\end{array}$} & \multirow[b]{2}{*}{ Subject } & \multirow[b]{2}{*}{$\underset{\text { utes }}{\text { Min- }}$} & \multirow[b]{2}{*}{ In. } & \multicolumn{6}{|c|}{ PAH } & \multicolumn{6}{|c|}{ Diodrast } & \multirow[b]{2}{*}{$\frac{E_{D}}{E_{P A B}}$} & \multirow[b]{2}{*}{$\frac{T_{D}}{T_{P A B}}$} \\
\hline & & & & $A_{0}$ & $\mathbf{E}$ & $\mathrm{Cl}$ & RPF & $\mathbf{T}$ & $\frac{10 T}{A_{0}}$ & $A_{0}$ & $\mathbf{E}$ & $\mathrm{Cl}$ & RPF & $\mathbf{T}$ & $\frac{10 \mathrm{~T}}{\mathrm{~A}_{0}}$ & & \\
\hline \multirow[t]{3}{*}{$5 t$} & \multirow{3}{*}{$\begin{array}{c}\text { Woman, } \\
26 \text { y., } \\
\text { b.s.a. } \\
1,69\end{array}$} & \multirow{3}{*}{$\begin{array}{r}17 \\
22 \\
14 \\
21 \\
12 \\
9 \\
12\end{array}$} & \multirow{3}{*}{$\begin{array}{r}102 \\
84 \\
97 \\
92 \\
91 \\
80 \\
83\end{array}$} & 74 & 92 & 450 & 490 & 27 & \multirow{3}{*}{$\begin{array}{c}, 67 \\
\text { Stee } \\
1,80 \\
1,71 \\
\text { Stee } \\
0,24 \\
0,41\end{array}$} & \multirow{2}{*}{$\begin{array}{c}104 \\
\text { concer } \\
623 \\
799\end{array}$} & 88 & $\begin{array}{r}546 \\
\text { increa }\end{array}$ & 623 & 49 & 4,71 & \multirow{2}{*}{$\begin{array}{l}0,96 \\
0,86 \\
1,00\end{array}$} & \multirow{2}{*}{$\begin{array}{l}1,79 \\
1,05 \\
1,18\end{array}$} \\
\hline & & & & $\begin{array}{l}516 \\
697\end{array}$ & $\begin{array}{l}43 \\
40\end{array}$ & $\begin{array}{l}260 \\
236\end{array}$ & $\begin{array}{l}605 \\
591\end{array}$ & $\begin{array}{r}93 \\
119\end{array}$ & & & $\begin{array}{l}37 \\
40\end{array}$ & $\begin{array}{l}238 \\
239\end{array}$ & $\begin{array}{l}644 \\
597\end{array}$ & $\begin{array}{r}98 \\
141\end{array}$ & $\begin{array}{l}1,57 \\
1,76\end{array}$ & & \\
\hline & & & & $\begin{array}{l}3,200 \\
2,530\end{array}$ & $\begin{array}{l}24 \\
23\end{array}$ & $\begin{array}{r}94 \\
112\end{array}$ & $\begin{array}{l}391 \\
448\end{array}$ & $\begin{array}{r}78 \\
103\end{array}$ & & $\begin{array}{c}\text { concen } \\
3,030 \\
2,360\end{array}$ & $\begin{array}{l}\text { tr. ir } \\
19 \\
20\end{array}$ & $\begin{array}{c}\text { increas } \\
90 \\
119\end{array}$ & $\begin{array}{l}\text { se } \\
473 \\
595\end{array}$ & $\begin{array}{r}95 \\
137\end{array}$ & $\begin{array}{l}\mathbf{0 , 3 1} \\
\mathbf{0 , 5 8}\end{array}$ & $\begin{array}{l}0,79 \\
0,80\end{array}$ & $\begin{array}{l}1,21 \\
1,33\end{array}$ \\
\hline \multirow[t]{2}{*}{6} & \multirow{2}{*}{$\begin{array}{c}\text { Man, } \\
21 \text { y., } \\
\text { b.s.a. } \\
1,75\end{array}$} & \multirow{2}{*}{$\begin{array}{l}19 \\
15 \\
21 \\
20 \\
22\end{array}$} & \multirow{2}{*}{$\begin{array}{l}170 \\
144 \\
142 \\
130 \\
155\end{array}$} & $\begin{array}{l}896 \\
950\end{array}$ & & $\begin{array}{l}213 \\
174\end{array}$ & & $\begin{array}{l}66 \\
50\end{array}$ & \multirow{2}{*}{$\begin{array}{l}0,74 \\
0,53 \\
\text { Stee } \\
0,74 \\
0,17\end{array}$} & \multicolumn{2}{|l|}{$\begin{array}{l}878 \\
930\end{array}$} & \multicolumn{2}{|l|}{$\begin{array}{l}272 \\
212\end{array}$} & $\begin{array}{l}131 \\
105\end{array}$ & $\begin{array}{l}1,49 \\
1,13\end{array}$ & & $\begin{array}{l}2,01 \\
2,13\end{array}$ \\
\hline & & & & $\begin{array}{l}1,327 \\
1,427\end{array}$ & & $\begin{array}{l}181 \\
141\end{array}$ & & $\begin{array}{l}98 \\
27\end{array}$ & & $\begin{array}{l}1,338 \\
1,453\end{array}$ & & $\begin{array}{l}177 \\
153\end{array}$ & & $\begin{array}{r}109 \\
72\end{array}$ & $\begin{array}{l}0,82 \\
0,49\end{array}$ & & $\begin{array}{l}1,11 \\
2,88\end{array}$ \\
\hline \multirow[t]{2}{*}{7} & \multirow{2}{*}{$\begin{array}{l}\text { Man, } \\
24 \text { y., } \\
\text { b.s.a. } \\
2,07\end{array}$} & \multirow{2}{*}{$\begin{array}{l}21 \\
25 \\
34 \\
22 \\
16\end{array}$} & \multirow{2}{*}{$\begin{array}{r}113 \\
105 \\
105 \\
101 \\
94\end{array}$} & $\begin{array}{l}797 \\
891\end{array}$ & & $\begin{array}{l}259 \\
219\end{array}$ & & $\begin{array}{l}131 \\
118\end{array}$ & \multirow{2}{*}{$\begin{array}{c}1,65 \\
1,33 \\
\text { Stee } \\
0,82 \\
0,56\end{array}$} & \multicolumn{2}{|l|}{$\begin{array}{l}854 \\
994\end{array}$} & \multicolumn{2}{|c|}{$\begin{array}{l}268 \\
220\end{array}$} & $\begin{array}{l}158 \\
147\end{array}$ & $\begin{array}{l}1,80 \\
1,48\end{array}$ & & $\begin{array}{l}1,21 \\
1,25\end{array}$ \\
\hline & & & & $\begin{array}{l}1,475 \\
1,835\end{array}$ & & $\begin{array}{l}168 \\
134\end{array}$ & & $\begin{array}{l}121 \\
103\end{array}$ & & $\begin{array}{l}1,490 \\
1,865\end{array}$ & & $\begin{array}{l}185 \\
148\end{array}$ & & $\begin{array}{l}164 \\
149\end{array}$ & $\begin{array}{l}1,10 \\
0,80\end{array}$ & & $\begin{array}{l}1,36 \\
1,43\end{array}$ \\
\hline $8 t$ & $\begin{array}{c}\text { Man, } \\
20 \text { y., } \\
\text { b.s.a. } \\
1,95\end{array}$ & $\begin{array}{l}14 \\
12 \\
13 \\
35 \\
11 \\
15 \\
10\end{array}$ & $\begin{array}{l}162 \\
158 \\
141 \\
142 \\
186 \\
197 \\
182\end{array}$ & $\begin{array}{r}560 \\
680 \\
770 \\
1,080 \\
1,410 \\
1,510 \\
1,640\end{array}$ & $\begin{array}{l}37 \\
41 \\
44 \\
36 \\
27 \\
29 \\
27\end{array}$ & $\begin{array}{l}394 \\
327 \\
281 \\
244 \\
249 \\
201 \\
211\end{array}$ & $\begin{array}{r}1,072 \\
802 \\
642 \\
680 \\
934 \\
683 \\
776\end{array}$ & $\begin{array}{r}146 \\
134 \\
128 \\
137 \\
134 \\
56 \\
87\end{array}$ & $\begin{array}{l}2,61 \\
1,97 \\
1,67 \\
1,27 \\
0,95 \\
0,37 \\
0,58\end{array}$ & $\begin{array}{r}570 \\
610 \\
680 \\
1,000 \\
1,280 \\
1,350 \\
1,460\end{array}$ & $\begin{array}{l}53 \\
48 \\
46 \\
34 \\
29 \\
31 \\
29\end{array}$ & $\begin{array}{l}423 \\
403 \\
350 \\
269 \\
277 \\
235 \\
241\end{array}$ & $\begin{array}{l}824 \\
841 \\
763 \\
796 \\
956 \\
757 \\
840\end{array}$ & $\begin{array}{l}173 \\
177 \\
167 \\
166 \\
181 \\
122 \\
160\end{array}$ & $\begin{array}{l}3,04 \\
2,90 \\
2,46 \\
1,66 \\
1,41 \\
0,91 \\
1,10\end{array}$ & $\begin{array}{l}1,43 \\
1,17 \\
1,04 \\
0,95 \\
1,07 \\
1,07 \\
1,07\end{array}$ & $\begin{array}{l}1,18 \\
1,32 \\
1,30 \\
1,21 \\
1,35 \\
2,18 \\
1,84\end{array}$ \\
\hline $9 \dagger$ & $\begin{array}{c}\text { Man, } \\
24 \text { y., } \\
\text { b.s.a. } \\
1,98\end{array}$ & $\begin{array}{l}18 \\
16 \\
15 \\
44 \\
24 \\
14 \\
13\end{array}$ & $\begin{array}{r}156 \\
133 \\
115 \\
86 \\
108 \\
102 \\
88\end{array}$ & $\begin{array}{r}700 \\
820 \\
900 \\
1,290 \\
1,950 \\
2,180 \\
2,320\end{array}$ & $\begin{array}{l}43 \\
36 \\
29 \\
23 \\
18 \\
18 \\
17\end{array}$ & $\begin{array}{r}235 \\
216 \\
220 \\
160 \\
138 \\
125 \\
99\end{array}$ & $\begin{array}{l}547 \\
596 \\
716 \\
696 \\
760 \\
705 \\
583\end{array}$ & $\begin{array}{r}74 \\
86 \\
112 \\
113 \\
95 \\
88 \\
60\end{array}$ & $\begin{array}{l}1,06 \\
1,05 \\
1,24 \\
0,88 \\
0,49 \\
0,40 \\
0,26\end{array}$ & $\begin{array}{r}680 \\
840 \\
950 \\
1,300 \\
1,970 \\
2,230 \\
2,380\end{array}$ & $\begin{array}{l}42 \\
42 \\
40 \\
26 \\
19 \\
20 \\
19\end{array}$ & $\begin{array}{r}245 \\
231 \\
223 \\
160 \\
147 \\
127 \\
99\end{array}$ & $\begin{array}{l}\mathbf{5 8 7} \\
\mathbf{5 4 7} \\
\mathbf{5 7 9} \\
\mathbf{6 2 1} \\
\mathbf{7 7 9} \\
\mathbf{6 3 6} \\
\mathbf{5 1 7}\end{array}$ & $\begin{array}{r}89 \\
112 \\
132 \\
127 \\
133 \\
118 \\
83\end{array}$ & $\begin{array}{l}1,31 \\
1,34 \\
1,39 \\
0,98 \\
0,68 \\
0,53 \\
0,35\end{array}$ & $\begin{array}{l}0,98 \\
1,17 \\
1,38 \\
1,13 \\
1,06 \\
1,11 \\
1,12\end{array}$ & $\begin{array}{l}1,20 \\
1,30 \\
1,18 \\
1,12 \\
1,41 \\
1,34 \\
1,38\end{array}$ \\
\hline
\end{tabular}

- Abbreviations as in Table I

t In $5,8,9$, the renal vein was catheterized.

TABLE III

Comparison between the simultaneous renal clearance $(C l)$ and renal extraction $(E)$ of $P A H$ and diodrast at low plasma concentrations of both substances

\begin{tabular}{|c|c|c|c|c|c|c|c|c|c|c|}
\hline \multirow{2}{*}{$\begin{array}{l}\text { Exp. } \\
\text { no. }\end{array}$} & \multirow[b]{2}{*}{ Sex } & \multirow{2}{*}{$\begin{array}{l}\text { Age } \\
\text { year }\end{array}$} & \multicolumn{3}{|c|}{ PAH } & \multicolumn{3}{|c|}{ Diodrast } & \multirow{2}{*}{$\frac{\mathrm{Cl}_{\mathrm{D}}}{\mathrm{Cl}_{\mathrm{PAB}}}$} & \multirow{2}{*}{$\frac{E_{D}}{E_{P A B}}$} \\
\hline & & & $\mathrm{Cl}$ & RPF & $\mathbf{E}$ & $\mathrm{Cl}$ & RPF & $\mathbf{E}$ & & \\
\hline $\begin{array}{r}1 \\
2 \\
3 \\
4 \\
5 \\
10 \\
11 \\
12 \\
13 \\
14 \\
15 \\
16 \\
17\end{array}$ & $\begin{array}{l}\mathbf{M} \\
\mathbf{F} \\
\mathbf{M} \\
\mathbf{M} \\
\mathbf{F} \\
\mathbf{M} \\
\mathbf{M} \\
\mathbf{M} \\
\mathbf{M} \\
\mathbf{M} \\
\mathbf{F} \\
\mathbf{M} \\
\mathbf{M}\end{array}$ & $\begin{array}{l}26 \\
26 \\
21 \\
26 \\
26 \\
25 \\
23 \\
25 \\
23 \\
23 \\
21 \\
22 \\
25\end{array}$ & $\begin{array}{l}529 \\
746 \\
587 \\
571 \\
460 \\
- \\
598 \\
440 \\
618 \\
492 \\
467 \\
544 \\
506\end{array}$ & $\begin{array}{l}577 \\
877 \\
630 \\
627 \\
501 \\
- \\
673 \\
490 \\
672 \\
557 \\
511 \\
594 \\
566\end{array}$ & $\begin{array}{l}92 \\
85 \\
93 \\
91 \\
92 \\
89 \\
89 \\
90 \\
92 \\
89 \\
91 \\
91 \\
90\end{array}$ & $\begin{array}{l}488 \\
673 \\
695 \\
632 \\
559 \\
585 \\
658 \\
410 \\
939 \\
525 \\
525 \\
482\end{array}$ & $\begin{array}{r}679 \\
832 \\
807 \\
780 \\
637 \\
720 \\
794 \\
470 \\
1,064 \\
627 \\
610 \\
570\end{array}$ & $\begin{array}{l}72 \\
81 \\
86 \\
81 \\
88 \\
81 \\
83 \\
87 \\
87 \\
84 \\
86 \\
86 \\
85\end{array}$ & $\begin{array}{l}0,92 \\
0,90 \\
1,18 \\
1,11 \\
1,21 \\
\overline{1,10} \\
0,93 \\
1,52 \\
1,07 \\
\overline{1,04} \\
1,05\end{array}$ & $\begin{array}{l}0,78 \\
0,95 \\
0,92 \\
0,89 \\
0,96 \\
0,91 \\
0,93 \\
0,97 \\
0,95 \\
0,94 \\
0,95 \\
0,95 \\
0,94\end{array}$ \\
\hline Mean & & & 547 & 606 & 90,3 & 598 & 716 & 83,6 & 1,09 & 0,926 \\
\hline$\sigma^{\cdot}$ & & & 85,2 & 105,2 & 2,06 & 138,0 & 154,2 & 4,20 & 0,175 & 0,0505 \\
\hline$\frac{100 \sigma}{M}$ & & & 15,6 & 17,4 & 2,3 & 23,1 & 21,5 & 5,0 & 16,0 & 5,5 \\
\hline
\end{tabular}


proportionality between $\mathrm{PAH}$ extraction and diodrast extraction was much more stable. As previously reported, the renal extraction of $\mathrm{PAH}$ was somewhat higher than that of diodrast, the difference between the means being highly significant $(P=0.001)$ by Student's " $t$ " test. Statistically, the difference between the means of the clearance values was not significant. As a consequence of the lower renal diodrast extraction and the higher diodrast clearance, the calculated figures for the renal plasma flow (RPF), calculated from the diodrast data, were higher than the corresponding figures, based on $\mathrm{PAH}$.

The analysis of $\mathrm{PAH}$ and diodrast in the renal venous samples, centrifuged after different time intervals, demonstrated that the shift of diodrast and $\mathrm{PAH}$ from erythrocytes to plasma after the first 40 seconds following sampling could influence the calculated extractions and RPF's only slightly (Figure 3). However, the shift during the first 40 seconds, which we were unable to study, may have been considerable.

\section{DISCUSSION}

The calculation of the tubular excretion, $\mathrm{T}$, at high plasma concentrations of diodrast or $\mathrm{PAH}$ is subject to error from several sources. Because $\mathrm{T}$ represents the small difference between the large amounts filtered and the larger total urinary excretion, analytical errors are of great significance. Variations in the percentage of the plasma diodrast or $\mathrm{PAH}$ filterable through the glomerular membranes are probably of even greater significance. In experiments on ultrafiltration of fresh human plasma containing high concentrations of diodrast and $\mathrm{PAH}$, we have obtained filterability factors which vary from 1 to 5 per cent in both directions from the classical figures of 73 per cent and 83 per cent. However, because in some experiments the filterable fraction slowly decreased, it may be that the duration of ultrafiltration is of some influence, since filtration in the capsula of Lavietes or in the centrifuged cellophane bag of Rehberg (15) took 5 to 10 hours. Moreover, filterability varied with the age of the sample. In some subjects, the changes did not exceed 1 to 2 per cent, but occasionally, after 24 hours, we found 2 to 6 per cent decreases in the ultrafilterability, and, at times, after 48 hours, decreases as great as 10 per cent. However, in fresh plasma, the proportion between the ultrafilterability of diodrast and of PAH remained reasonably steady.

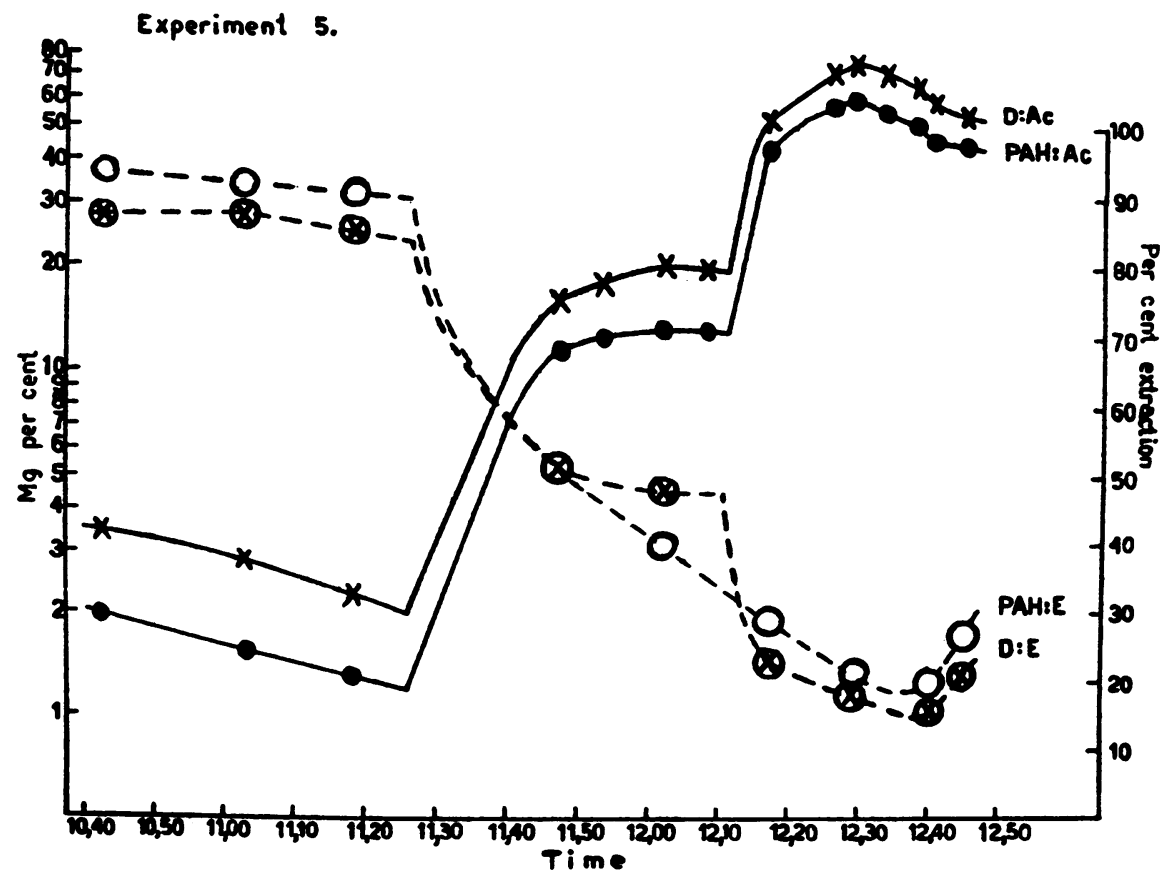

Fig. 2. Results of Renal Vein Catheterization-Experiment 5

Symbols and abbreviations as in Figure 1. 


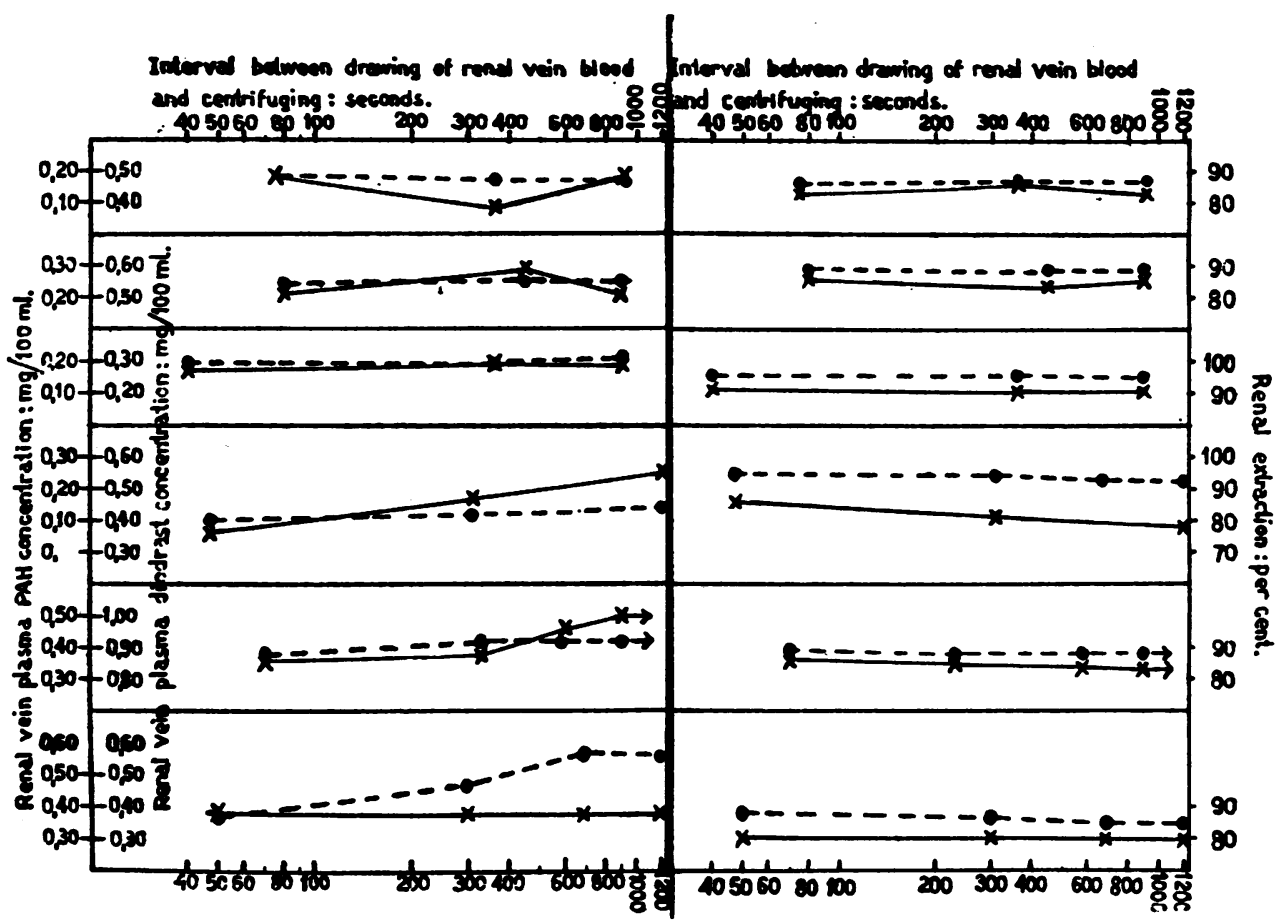

Fig. 3. Renal Venous Plasma Concentrations (Left-half of Chart) and Renal Extractions (Right-Half of Chart) for Diodrast (X) and PAH ( $\bullet$ ) Blood Centrifuged 50 to 1,200 Seconds after Collection

In the experiments recorded in the tables, the ultrafiltration was performed on 1 to 2 day old samples. Hence, we have preferred to calculate $T$ values, with reservations, on the basis of the usual ultrafilterabilities of 73 per cent and 83 per cent.

When calculated in terms of molecules, the Tvalues for diodrast and $\mathrm{PAH}$ were essentially the same when plasma concentrations were below the saturation limit; i.e., the proportion between the tubular excretion and the arterial plasma concentration, $T / A_{c}$, was of the same order of magnitude for both substances (Table I). However, at plasma concentrations above the saturation limit, the tubular excretion of diodrast exceeded that of $\mathrm{PAH}$; i.e., its $\mathrm{T} / \mathrm{A}_{c}$ ratio was higher even if it were assumed that both substances were completely filterable.

The data in Table III demonstrate that at low plasma concentrations the renal plasma flow, calculated on the basis of diodrast, was significantly higher than the corresponding $\mathrm{PAH}$ value, although there was no significant difference between the corresponding clearances.
At low plasma concentrations, the ratio of diodrast extraction to $\mathrm{PAH}$ extraction was slightly below 1 and remained remarkably steady, whereas the corresponding clearance ratio was above 1 but had a high standard variation. When the plasma concentration of both substances was very high, the percentage extractions were nearly identical, with a few exceptions (Table II). If the arterial plasma concentration of one of the substances was maintained at a constant low level when the concentration of the other was suddenly increased, there resulted simultaneous and equivalent depression of both $E_{P A B}$ and $E_{D}$ (Table I).

The accumulation of diodrast in the renal tubular cells, found by Engstrom and Josephson (16), could not have induced the higher tubular excretion and renal venous concentration of diodrast. As shown with PAH by Josephson, Bucht, Ek and Werkö (13), such accumulation can influence the tubular excretion and the renal vein plasma concentration only when the plasma concentration is rapidly increased or decreased. The differences found here remained fairly steady over a long period and represented much larger 
amounts of diodrast than could be explained by this process.

White, Findley, and Edwards (17), and Corcoran, Smith, and Page (18) have suggested that diodrast may shift from the erythrocytes to the plasma during the passage of the blood through the kidneys. This shift may explain the observed differences in the renal percentage extractions of diodrast and PAH.

The fact that these substances mutually depressed each other's tubular excretion indicates that either they are excreted by the same transferring mechanism, as postulated by Smith, Finkelstein, Aliminosa, Crawford, and Graber (7), or that the energy required for their excretion is provided by a common source. The fact that at higher plasma concentrations more molecules of diodrast than of $\mathrm{PAH}$ are excreted should result in a higher renal extraction for diodrast than for PAH under these conditions. However, the anticipated difference may be negated by the shift of diodrast from the erythrocytes to the plasma. At low plasma concentrations, when the two substances are almost equally excreted, the shift of diodrast may increase the renal vein plasma concentration, and thereby produce the apparent, lower renal extraction of diodrast with the consequent, apparent, higher renal plasma flow. The suggested shift must be so rapid that it cannot be prevented by almost immediate centrifugation of the renal venous blood. At high plasma concentrations, the percentage of plasma diodrast excreted by the tubules is small. Consequently, the plasma/erythrocytes concentration ratio is only slightly changed and the influence of the shift not measurable.

\section{SUM MARY}

Injections of $\mathrm{PAH}$ and diodrast were given simultaneously to 17 healthy human subjects. In 15 of these, renal venous blood for repeated analyses was obtained by venous catheterization.

When the plasma concentrations of $\mathrm{PAH}$ and diodrast were low, the proportions between both their respective percentage renal extractions from the plasma and their respective tubular excretions were remarkably steady.

When the plasma concentration of one of the substances was increased, the percentage renal extraction of both was equally depressed. With increasing plasma concentration, the tubular excretion of diodrast increases relative to the $\mathrm{PAH}$ excretion. It is concluded that the two substances are probably excreted by the same mechanism, which, at high plasma concentrations, can transport more diodrast molecules than PAH.

It is suggested that a shift of diodrast from the erythrocytes during the passage through the kidney may increase the renal venous plasma concentration. At high plasma diodrast concentrations, the influence of this shift is not measurable, but at low concentrations it leads to a lower, apparent value of renal percentage extraction for diodrast as compared to PAH.

\section{REFERENCES}

1. Smith, H. W., Goldring, W., and Chasis, H., The measurement of the tubular excretory mass, effective blood flow and filtration rate in the normal human kidney. J. Clin. Invest., 1938, 17, 263.

2. Rammelkamp, C. H., and Bradley, S. E., Excretion of penicillin in man. Proc. Soc. Exper. Biol. \& Med., 1943, 53, 30.

3. Beyer, K. H., Peters, L., Woodward, R., and Verwey, W. F., The enhancement of the physiological economy of penicillin in dogs by the simultaneous administration of para-amino-hippuric acid. II. J. Pharmacol., 1944, 82, 310.

4. Sperber, I., The excretion of some glucuronic acid derivatives and phenolsulphuric esters in the chicken. Ann. Roy. Agricult. Coll. Sweden, 1948, $15,317$.

5. Sperber, I., The excretion of piperidine, guanidine, methylguanidine and $\mathrm{N}^{\mathrm{I}}$-methylnicotinamide in the chicken. Ann. Roy. Agricult. Coll. Sweden, 1948, $16,49$.

6. Puck, T., Wasserman, K., and Fishman, A., Some effects of inorganic ions of the active transport of phenol red by isolated kidney tubules of the flounder. J. Cell. \& Comp. Physiol., 1952, 40, 73.

7. Smith, H., Finkelstein, N., Aliminosa, L., Crawford, B., and Graber, M., The renal clearances of substituted hippuric acid derivatives and other aromatic acids in dog and man. J. Clin. Invest., 1945, 24, 388.

8. Josephson, B., Wërko, L., and Bucht, H., The renal extraction of diodrast in man. Scandinav. J. Clin. \& Lab. Invest., 1950, 2, 149.

9. Bucht, H., Examination of the renal plasma flow by means of para-amino-hippuric acid (PAH) using one intra-muscular injection. Scandinav. J. Clin. \& Lab. Invest., 1949, 1, 126.

10. Josephson, B., Examination of diodrast clearance and tubular excretory capacity in man by means of two 
single injections of diodrast (Umbradil). Acta med. Scandinav., 1947, 128, 515.

11. Phillips, R. A., Dole, V. P., Hamilton, P. B., Emerson, K., Jr., Archibald, R. M., and Van Slyke, D. D., Effects of acute hemorrhagic and traumatic shock on renal function of dogs. Am. J. Physiol., 1946, 145, 314.

12. Bucht, H., Studies on renal function in man with special reference to glomerular filtration and renal plasma flow in pregnancy. Scandinav. J. Clin. \& Lab. Invest., 1951, 3, suppl. 3, 1.

13. Josephson, B., Bucht, H., Ek, J., and Wërko, L., Renal extraction, its depression, and the tubular storage of para-amino-hippuric acid (PAH) in the healthy and in the diseased human kidney. Scandinav. J. Clin. \& Lab. Invest., 1952, 4, 1.
14. Josephson, B., Kallas, J., Kakoussaios, G., and Greig, A., Renal tubular excretion from high plasma levels of para-amino-hippuric acid and diodrast in unanaesthetized rabbits. Acta physiol. Scandinav., in press.

15. Rehberg, P. B., A centrifugation method of ultrafiltration using cellophane tubes. Acta physiol. Scandinav., 1943, 5, 305.

16. Engstrom, A., and Josephson, B., Historadiographic demonstration of diodrast in the rabbit kidney. Am. J. Physiol., in press.

17. White, H. L., Findley, T., Jr., and Edwards, J. C., Interpretation of diodrast clearances in man. Proc. Soc. Exper. Biol. \& Med., 1940, 43, 11.

18. Corcoran, A. C., Smith, H. W., and Page, I. H., The removal of diodrast from blood by the dogs explanted kidney. Am. J. Physiol., 1941, 134, 333. 